\title{
The First 1000 Days: catalysing equity outcomes for Aboriginal and Torres Strait Islander children
}

\section{Champions needed to scale up childhood equity efforts, not short-term solutions in ill conceived policy}

n January 2014, Prime Minister Abbott set a target of bridging the gap in school attendance between Indigenous and non-Indigenous pupils within 5 years by employing truancy officers in communities. ${ }^{1}$ But what about children who cannot attend school full-time for behavioural or developmental reasons? We need to change the early childhood agenda from one of school preparation to one that addresses developmental delays early, so children are better prepared for school. ${ }^{2,3} \mathrm{We}$ need a push for more action, greater coordination and stronger investments to ensure early equity targets are met. We need all governments to continue commitments to saving the next generation from the challenges of inequity - it's time to revisit a few fundamentals of human development at a time in a child's life when changes in service integration and family engagement can deliver on the promise of childhood equity.

The first change is to overcome the fragmentation of local health, education, welfare, justice and other social services. ${ }^{4}$ Second, we need to ensure services are knitted together at a regional level under Aboriginal and Torres Strait Islander leadership. ${ }^{5}$ Finally, we need a high-quality evidence base to underpin programs that are grounded both in the neuroscience of early brain development and in the complex effects of social and community environments on children's development. ${ }^{6}$ Coordinated interventions that properly engage parents and vulnerable children with interrelated issues - such as maternal mental health, parental incarceration, racism and familial stress - and also engage with the child protection and welfare systems have the best chance of being effective.

We need frameworks promoting multi-agency strategies that engage families to focus on the early period of child development, from conception to age 2 years. A possible template for this is a program now being used to organise effort in low- and middle-income countries the "First 1000 Days". 7

\section{The "First 1000 Days" approach}

Internationally, the First 1000 Days is focused on reducing undernutrition around the globe. Combining evidencebased medical care and social support, it includes actions that target:

- adolescents - through healthy behaviour modification, delaying pregnancy and parenting education;

- women of reproductive age - with preconception care, good nutrition, healthy lifestyle education and strategies to reduce gestational diabetes;

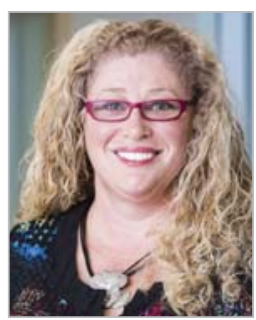

Kerry Arabena Chair of Indigenous Health and Director Onemda VicHealth Koori
Health Unit, University of Melbourne, Melbourne, VIC.

kerry.arabena@ unimelb.edu.au

doi: $10.5694 / \mathrm{mjal} 4.00343$

Provenance: Commissioned; not externally peer reviewed.

1 Harrison D. Prime Minister Tony Abbott sets target on Indigenous pupils' school attendance. Sydney Morning Herald 2014; 13 Feb. http://www.smh.com.au/federal-politics/political-news/prime-ministertony-abbott-sets-target-on-indigenous-pupils-school-attendance-20140212-32icv.html (accessed Mar 2014).

2 Council of Australian Governments. Investing in the early years - a national early childhood development strategy. Canberra: COAG, 2009. https://www.coag.gov.au/node/205 (accessed Apr 2014).

3 Council of Australian Governments. Closing the gap: national partnership agreement on Indigenous childhood development. Canberra: COAG, 2009. https://www.coag.gov.au/node/143 (accessed Apr 2014)

4 Wise S. Improving the early life outcomes of Indigenous children: implementing early childhood development at the local level. Canberra: AlHW, 2013. http://www.aihw.gov.au/closingthegap/ ItemDetails.aspx?id=300\&type=pb (accessed Apr 2014).

5 Mustard F. Investing in the early years: closing the gap between what we know and what we do. Adelaide: Government of South Australia, 2007. http://www.thinkers.sa.gov.au/thinkers/mustard/report.aspx (accessed Apr 2014).

6 Winter P. 2010 Engaging families in the early childhood development story: a national project conducted on behalf of the Ministerial Council for Education, Early Childhood Development and Youth Affairs. http:// www.mceecdya.edu.au/verve/_resources/ECD_Story-Neuroscience_and_early_childhood_dev.pdf (accessed Mar 2014).

7 Executive summary of The Lancet maternal and child nutrition series. London: Lancet 2013; Jun 6. http:// www.thelancet.com/series/maternal-and-child-nutrition (accessed Apr 2014).

8 Bhutta ZA, Das JK, Rizvi A, et al. Evidence-based interventions for improvement of maternal and child nutrition: what can be done and at what cost? Lancet 2013; 382: 452-477. 